\title{
Memory and History in Junot Díaz's The Brief Wondrous Life of Oscar Wao
}

\author{
Lestari Manggong \\ \{lestari.manggong@unpad.ac.id \\ English Studies Program Universitas Padjadjaran, Jalan Raya Bandung-Sumedang Km. 21 Jatinangor, \\ Sumedang, Jawa barat
}

\begin{abstract}
Postmodern and magic realistic in nature, The Brief Wondrous Life of Oscar Wao, a novel by a contemporary Latin American author Junot Díaz, collates memory and history through the narrator's perception. This essay aims to discuss the different degree of perceptions of the Dominican Republic based on the memory and tale of the Fuku through shifts of focalizations in identifying Oscar Wao's Hispanic heritage. The analytical methodology will have its base on the characteristics of Latin American literature, focusing on issues namely: narrating uncertainty, marginalization, and dehistorization. The main finding of this essay shows that being hybrid in nature, Oscar Wao is symptomatic as having comic realistic view upon identifying his Latin American self. The argument proposed in this essay is that in the novel, there is a narrative tendency of dehistoricizing the Dominican Republic as a reaction to the need to assimilate in the U.S. soil.
\end{abstract}

Keywords: Junot Díaz, Latin American literature, memory, history, dehistorization.

\section{Introduction}

Junot Díaz, a contemporary Latin American author, is known for his masterpiece, The Brief Wondrous Life of Oscar Wao (Oscar Wao in short), a novel both comical and fantastical [2], [5] in nature. Oscar, the main character in the novel, is a sci-fi, Japan animation, and Marvel comics nerd. What is worse, he is an overweight adolescent of Dominican descent living in a vibrant neighborhood of New Jersey. The narrative experiences changes in track from the narrator to Oscar's sister, to his mother, his grandparents, and back to Oscar with Yunior the narrator slipping in and out of their narratives. The intertextuality in the novel made apparent by the use of footnotes and notes on historical references inside the narratives reflects that the novel has a lot to carry. And this prompts a question that this essay aims to find the answer to: what is the socio-political and historical background that causes the narrative to have these maneuvers?

We learn that the novel collates memory and history as depicted through the narrator's perception on the Dominican Republic under the dictatorship of Rafael Trujillo. In this light, this essay aims to discuss the different degree of perceptions of the Dominican Republic based on the memory and tale of the fukú from Oscar's New Jersey ghetto dwelling. As a narrative told by a Latin American immigrant, the analytical methodology on the characteristics of Latin American literature in the discussion refers to [4]. Narratologically, the discussion also focuses on the effects of shifts of focalizations to the way Oscar identifies his Hispanic heritage. The main finding of this essay shows that being hybrid in nature, Oscar Wao is symptomatic as having comic realistic view upon identifying his Latin American self. The argument proposed 
in this essay is that in the novel, there is a narrative tendency of dehistoricizing the Dominican Republic as a reaction to the need to assimilate in the U.S. soil.

\section{Research Method}

The method used to discuss the novel is literary analysis focusing on issues such as narrating uncertainty, marginalization, and dehistorization. The discussion on narrating uncertainty refers to a postulation that the literary/aesthetic operations carried out in a Latin American novel are already present within the cultural fields of the writer [1]. In the discussion, this bases the notion that Oscar Wao emerges as narrative of uncertainty. By looking at the novel as such, the discussion further develops to formulating the type of marginalization being carried out. To do this, I will particularly look at Oscar as a doubly marginalized figure; him as a nerdy Dominican-American working class living in New Jersey. I will also show that the hybrid nature of Oscar is inevitably told through intertextual history related to the fukú, since "genealogy is a fundamental element in modern Latin American fiction" [5]. The discussion will ultimately show a narrative tendency of dehistorization of the Dominican Republic, as this can be seen as a way to maneuver in assimilation. These issues are put under a microscope within the context of Latin American literature. For this, the discussion also needs to look at the characteristics of Latin American literature. This will have its base from looking back to the history of Latin American literature up to contemporary era. The three main issues will be dissected by paying close attention to the shifts of focalizations in identifying Oscar Wao's Hispanic heritage.

Discussion on Oscar Wao to date has had its focus on "fukú americanus" [12], intertextuality and marginalization [10], and African heritage of the Dominicans [6]. Saldíivar's observation looks particularly at the way the novel "seeks both to reveal the ways in which the power-knowledge couplet has been at work in creating that colonial difference, as well as the way in which colonial and imperial power represents difference" [12]. Saldíivar's tackling on "fukú americanus" translated in his own neologism "fukú Americanity" in the discussion of this essay helps to see the way memory and history are collated in the novel. O'Brien's observation on intertextuality and marginalization in Oscar Wao helps enrich the discussion in this essay in a way that it provides a look at how intertextuality gives an interpretation on how marginalization is presented in the novel. Lastly, González's observation helps to understand why Díaz's novel contributes to a different view on seeing a more complex side of Latin American literature.

\section{Oscar Wao in Latin American Literature}

\subsection{A Brief Summary of Oscar Wao}

The research object in question is Junot Díaz's 2008 Pulitzer Prize and the National Book Critics Circle Award-winning novel, The Brief Wondrous Life of Oscar Wao. Oscar de Léon (Oscar Wao), the main character in the novel, is a nerdy Dominican-American growing up in the 1980s New Jersey who is bashful and overweight, whose ambition is to write a space fantasy epic. In his "adolescent alienation" [9], Oscar wonders if he will ever have sex. Aside from Oscar, the novel also provides a portion of Lola's story. As Oscar's sister, Lola struggles with her love-hate relationship with her mother, Beli. After catching up with Oscar during his time 
at university, the narrative presents Beli's formative years in the Dominican Republic under Rafael Trujillo, who ruled the country from 1930 to 1961. Afterwards, the narrative goes back further to Beli's parents' experience of the Trujillo regime.

Oscar moves to the Dominican Republic and falls in love with Ybon, a prostitute living near his place. Ybon's boyfriend becomes jealous of Oscar and sends his men to beat him up. The attack causes Oscar to have a coma, and his family takes him back to the United States. Oscar recovers and borrows money from Yunior, his friend, who is also the narrator of the story, and returns to the Dominican Republic. There, he stalks Ybon and she eventually has sex with Oscar. Another misfortune catches up with Oscar again. Ybon's boyfriend's men find Oscar, take him back to the sugarcane fields, and kill him.

\subsection{Latin American Literature: Characteristics}

Over the years, debates over when Latin American literature has its start have been varied. Latin American literature is reciprocal with another term, Spanish American literature, due to the language used in the text and the country of origin of the authors. In terms of Spanish American literature, I chose to lean towards the following conception:

If the idea of Spanish American literature has existed since the beginning of the nineteenth century, and if the very idea of literature has also existed only since that period, then Spanish American literature has existed since there has been literature. In this sense, it is not a recent literature, as some would suggest, but rather a literature whose foundational peculiarities are more concrete and intense than those of European literatures, but not necessarily different [4].

In the citation, European literature is compared with Spanish American literature due to the fact that Spain (whose language a majority of Spanish or Latin American authors use) is part of Europe. Echevarria argues that different from European literature, Spanish American literature has more weight due to its peculiarity. Furthermore, in the argument we can see that Spanish American literature is not recent, and this is what causes it to have that peculiarity. ${ }^{1}$ In the discussion of Díaz's novel, it is this peculiarity that bases the way the novel is perceived. Due to its very early point of departure, I argue that Spanish American literature, which in this context specifically refers to the most common used term: Latin American literature, is complex in both structure and theme.

The complexity of structure and theme in Latin American literature has been intensely prevalent in the works of modern Latin American literature, namely those by Isabel Allende in the early 1980s and Julia Alvarez in the early 1990s [6]. In support to this, Swanson observes that "most notably from the 1970s onwards, Latino fiction written in English has emerged as the principal manifestation of Hispanic writing in the US" [13]. Junot Díaz, who gained recognition in the early 1990s, can be said to have voiced similar concerns as that of Allende's and Alvarez's in terms of problematizing the hybrid nature of Latin Americans in the U.S. In Latin American literature, such a problematization emerges in effect to the often partial and incomplete discursive historical consciousness [11]. Like many other Latin American authors before him, Díaz tackles with issues faced by Hispanic immigrant in the U.S. Swanson notes that “Argentina's Luisa Valenzuela and Chile's Isabel Allende have lived or live in North

${ }^{1}$ For instance, historical events as early as $1500 \mathrm{BC}$ has been recorded in works of literature by Pablo Neruda, The Heights of Macchu Picchu [8]. 
America and write about the North American experience" [13], and it is within this similar tone that Dominican American Díaz reflects the experience of Dominican-descent Americans in Oscar Wao.

\section{Oscar Wao as a Narrative of Uncertainty Collating Memory and History}

The discussion on the uncertainty of narrative in Oscar Wao has its base on the concept of narrating uncertainty, a mode of writing influenced by the series of conflicted history in Latin American countries during the early 1980s, as argued by Ares. Ares notes that during the 1980s

most Latin American countries were slowly returning to democracy after years of brutal military regimes ... [with] the most distinctive trend of the 1960s and 1970s was the uprising of a wide variety of guerrilla movements and a series of violent military coups (from Peru in 1968 to Argentina and Ecuador in 1976) [1]

Ares further argues that "in the 1980s, Latin American literary production showed signs of a paradoxical situation: a large number of novels reviewed historical narratives in an attempt to explain the roots of violence and the failures of the 1960s revolutionary aspirations" [1]. This tendency can still be seen in Oscar Wao, which was published in the early 21 st century. The paradoxical situation is presented through the use of historical narrative traced back to the curse of the fukú. In the novel, the fukú is associated with the Admiral [3], who supposedly is Christopher Columbus, the historically well-known figure who discovered the New World. In this manner, the novel seems to put the blame on the discovery, which inadvertently blames Europe for causing the long history of colonialism. González observes that the name Christopher Columbus is intentionally erased in an attempt to keep "full knowledge just out of a reader's reach" [6], giving the effect that the novel distances itself from the real world. In sync to this, Oscar is also presented as distancing himself from the real world as a nerdy character who loves sci-fi, fantasy fiction, and comic books. He is even described as having the main goal to write a space fantasy epic. This distancing, in my argument, can thus be perceived as a manifestation of creating a narrative of uncertainty. Within this frame of narrative uncertainty, as a doubly marginalized figure, Oscar is put as a figure to articulate the hybrid nature of a working class Dominican-American living in New Jersey. The complex nature of Latin American history is represented by the complex narrative of the novel; aside from having shifts of focalizations, the novel also provides footnotes ${ }^{2}$ that give brief explanation on Trujillo for instance, or the fukú and its origin.

The complexity of the novel is also shown through the layers of memory presented through different focalizations. In part Two, the narrative is focalized by Lola, Oscar Wao, reflecting her love-hate relationship with her mother, Beli. Lola describes herself as a "devil-bitch" "punk chick" [3]. She refers her mother as her "Old World Dominican mother" [3], which raises further questions on how the novel sees the Dominican Republic, the imaginary country of origin to both diasporic Lola and Oscar. As part of the Latin American region, the Dominican Republic is historically part of the New World. Lola's labeling her mother as such indicates that she perceives Beli as similar to those coming from the Old World, in this case, Europe. In a way, Lola blames her mother's Old World upbringing for what she turns out to be. In contrast, when

${ }^{2}$ Read O'Brien [10] for thorough investigation on the use of footnotes in the novel. 
telling the story of Beli in Part Three, the narrator (Yunior) explicitly says that "Dominicans are Caribbean and therefore have an extraordinary tolerance for extreme phenomena" [3]. From this, we can see that the narrator and Lola have different views on what Dominicans are. Lola's memory of Beli, and Beli's memory of her mother are collated and at the same time juxtaposed with the history of dictatorship in the Dominican Republic led by Trujillo. Trujillo's dictatorship is associated with gangster-mode business that involves Beli and thus gives effect to the way her children are raised.

Towards the end of the novel, Oscar's going back to Dominica reveals yet another side of how the narrative views Oscar's imaginary homeland. History repeats itself when Oscar is taken to a cane-field to be beaten up by Ybon's boyfriend's men, to which the narrator says, "How's that for eternal return?" [3]. The cane-field seems to be put as a trope that indicates a place of surrender. In Beli's case, it is a place of surrendering herself to God, whereas in Oscar's case, it is a place of surrendering his life. In this sense, the narrative puts Dominica as an ambiguous space that gives and takes; it gives Beli's life and it takes Oscar's. At this point, the novel seems to present a contrasted view of Dominica and America. Dominica the imaginary homeland is presented not as Oscar's cradle of life, but the opposite of that. America, on the other hand, is a home to Oscar that accommodates his hybridity.

\section{Dehistorization in Oscar Wao}

From the discussion, it is apparent that the use of memory and its collation with history leads to a critical perception on Dominica and America. The novel's very concept of the fukú americanus as "an attempt to reveal and displace the logic by which Europeans have represented their others" [12] is instrumental in collating the two, highlighting how the intermingling of the two provides a discourse for the novel to perceive Dominica and America as the one and the other. As such, it can be argued that the novel presents a form of dehistorization by not drawing a clear line between the two. To conclude, I would lean towards this quote: "Novels dissected and rewrote historical events, re-created or replaced social subjects, and attempted to give voice to those forgotten by history" [1]. In this sense, Oscar Wao is best seen as a discursive space for Dominican Americans to articulate themselves as part of Latin Americans.

\section{References}

[1] Bautista, Daniel. Comic Book Realism: Form and Genre in Junot Díaz's The Brief Wondrous Life of Oscar Wao. Journal of the Fantastic in the Arts. 2010; Vol. 21, No. 1 (78): pp. 41-53.

[2] Echevarria, Roberto Gonzalez. Myth and Archive: A Theory of Latin American Narrative. Cambridge: Cambridge University Press; 2009.

[3] Echevarria, Roberto Gonzalez. The Cambridge History of Latin American Literature Volume I: Discovery to Modernism. Roberto Gonzalez Echevarria and Enrique PupoWalker (Eds.). U.K.: Cambridge University Press; 2006. A brief history of the history of Spanish American Literature; pp. 7-32.

[4] Ares, Silvia G. Kurlat. A Companion to Latin American Literature and Culture. Sara Castro-Klaren (Ed.). U.K: Blackwell Publishing; 2008. Post-Utopian Imaginaries: Narrating Uncertainty; pp. 620-635.

[5] Saldíivar, Joséé David. Conjectures on "Americanity” and Junot Dííaz's "Fukú Americanus" in The Brief Wondrous Life of Oscar Wao". The Global South. 2011; Vol. 5 , No. 1, Special Issue: The Global South and World Dis/Order (Spring 2011), pp. 120-136. 
[6] O'Brien, Sean P. Some Assembly Required: Intertextuality, Marginalization, and The Brief Wondrous Life of Oscar Wao. The Journal of the Midwest Modern Language Association. 2012; Vol. 45, No. 1 (Spring 2012); pp. 75-94.

[7] González, Christopher. Reading Junot Díaz. U.S.A: University of Pittsburgh Press; 2015.

[8] Mutizwa, Kadzi. Assimilation Anxiety: The Brief Wondrous Life of Oscar Wao by Junot Díaz (Review). New Labor Forum. 2009; Vol. 18, No. 1 (Winter, 2009); pp. 116-119.

[9] Kristal, Efraín. The Cambridge Companion to the Latin American Novel. U.K.: Cambridge University Press; 2006. Introduction; pp. 1-22.

[10] Swanson, Philip. Latin American Fiction: A Short Introduction. U.S.A.: Blackwell Publishing; 2005.

[11] Ortega, Julio. Transatlantic Translations: Dialogues in Latin American Literature. Philip Derbyshire (Trans.). London: Reaktion Books; 2006.

[12] Moss, Joyce and Lorraine Valestuk. World Literature and Its Times: Profiles of Notable Literary Works and the Historical Events that Influence Them, Volume1: Latin American Literature and Its Times. U.S.A: Gale Group;1999.

[13] Díaz, Junot. The Brief Wondrous Life of Oscar Wao. U.S.A.: Riverhead Books; 2007. 